\title{
REFLECTION ON THE 1976 TORONTO OLYMPIAD FOR THE PHYSICALLY DISABLED
}

\author{
By Sir Ludwig Guttmann, C.B.E., F.R.S. \\ Stoke Mandeville National Sports Stadium for the Paralysed and Other Disabled, \\ Aylesbury, England
}

Abstract. A report is given on the various aspects of the 1976 Olympiad of the Physically Disabled. The aspects discussed are the historical background, planning and preparation of the Games, accommodation for amputees, blind and paraplegics, transport, games site, organisation of sports events, medical supervision, publicity of the Games, standards of performance and records and last, but by no means least, politics and sport.

Key words: Toronto Olympiad of the disabled; planning and organisation of the Olympiad; medical supervision of the Olympiad; politics in sport for the disabled.

\section{Historical Background}

SiNCE the Stoke Mandeville Games for the Paralysed became an international sports movement and, in due course, developed into a world wide sports event for the paralysed, they have been held annually on the sportsground of Stoke Mandeville Hospital. They take place at the end of July in memory of the foundation of these Games in 1948, and every 4th year, if possible, in the host country of the Olympic Games. Moreover, this international sports event differs from the Olympics of the able-bodied in that it is not only champions who are allowed to compete but also less skilled athletes to help in their physical, psychological and social rehabilitation through the means of sport.

The first Games outside Stoke Mandeville were held in 1960 in Rome, immediately after the Olympic Games. The competitors and escorts were housed in the Olympic Village and the Games were held in one of the Olympic Stadia. The second Olympiad took place in 1964 in Tokyo, under the same conditions, where in 5 days we had no less than over 100,000 spectators. The Tokyo Games had far-reaching effects from the point of social reintegration, as the Japanese Government, having realised what paralysed in their wheelchairs could do in sport, set up within 6 months after the Games the first factory for severely disabled which, in due course, increased to four such factories, now called Sun Industries. In I968, the Organising Committee of the Olympic Games in Mexico were unable to host the Games for the Paralysed in addition to the Olympics for the able-bodied. Therefore, we received invitations from other countries and at the unanimous decision of the International Stoke Mandeville Games Executive Committee, accepted Israel, where 750 competitors from 29 countries took part. In the Olympic year of 1972 when the Olympics took place in Germany, it was not possible to hold our Games either before or after the Olympic Games at the magnificent Olympic Stadium in Munich, because of lack of adequate accommodation for wheelchair athletes. It was the City and University of Heidelberg which became hosts to our Games, where Iooo paraplegic sportsmen and women of 45 countries took part. The Games were always opened by leading personalities of the State or the Royal Household of the host countries, who readily recognised the 
immense value of sport not only for the social reintegration of the severely disabled into the community but also as an education to the public at large.

In the Olympic year 1976, our Games could not be held in Montreal; therefore, the Etobicoke Borough of Toronto offered to be the host of our Olympiad. The Toronto Olympiad was the first where not only spinal paraplegics and tetraplegics, although in the majority, were to take part, but also amputees and blind. Professor R. W. Jackson, who had attended international games held in 1964, where he became convinced and most enthusiastic about the importance of sport for the physical, psychological and social rehabilitation of these severely disabled, was made the Chairman of the Organising Committee and $\mathrm{Mr}$ Dick Loiselle the Executive Director of the Committee. It was agreed to accept I Io0 paraplegics and for the first time 600 amputees and blind. This placed, of course, an increased burden on the organisers with regard to the accommodation of this great number of competitors and their escorts, and it was not possible to accommodate all teams in one place. It was decided to house the paraplegic sportsmen and women at York University and the amputees and blind at Toronto University.

The budget for these Games was calculated to be 2 million dollars of which 500 thousand dollars would be given each by the Federal Government of Canada, the Provincial Government of Ontario, and the Metropolitan Government of Toronto, the remainder to be met by public subscription.

At the invitation of the Canadian Organising Committee, Miss Joan Scruton, M.B.E., the Secretary General of both I.S.M.G.F. and I.S.O.D., Mr Charles Atkinson, Senior Technical Officer of Sport, and myself as President of both the above-mentioned international sports organisations, paid a visit to Toronto in September 1975. We visited the new Sports Centre called Olympium, still under construction, at Etobicoke and part of the Centennial Park Sports Arena. The plan of the Olympium was excellent and good progress of the building had already been made. This Centre has a large hall for volley ball and basketball, an Olympic swimming pool of $50 \mathrm{~m}$, a lift, a lounge, smaller rooms for meetings and a cafeteria. Archery, dartchery, fencing, weight lifting, track events (wheelchair races up to I500 $\mathrm{m}$ ) as well as pentathlon, field events, table tennis were to be held at the arena and the Stadium of the Centennial Park with its large spectator stands. A field hospital was to be installed at the nearby Hollycrest School, organised and conducted by a team of Canadian physicians and surgeons with a rest centre for competitors and scientific research facilities. Snooker competitions were to be housed in the nearby Seneca School and the bowls competitions were to be held at the excellent Etobicoke bowling green situated in another part of the borough of Etobicoke.

\section{Early Publicity}

From the start the Canadian press, radio and television fully supported our Games and were very active in arousing interest in this venture of sport and humanity. To help in the publicity, Dr Jackson and I gave lectures to medical and paramedical people and to various sub-committees of the Organising Committee, and many press, radio and television interviews were held. Interest and enthusiasm of all concerned in this Olympiad was already very apparent.

\section{First Political Intrusion}

In January 1976 the Organising Committee was faced with a serious financial crisis, for the Canadian Federal Government, which from the beginning had been 

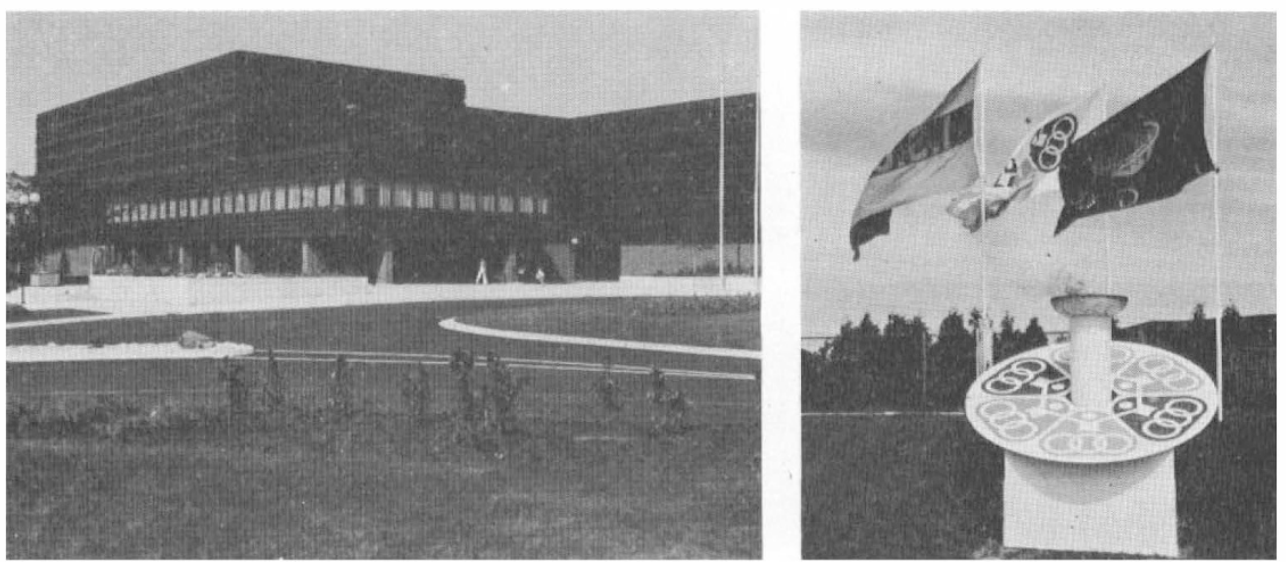

Fig. I (left)

The Olympium of Centennial Sports Arena and Stadium.

FIG. 2 (right)

The Olympic flame with the ISMG, ISOD and the Olympiad flag.

aware of the participation of our fully socially and racially integrated member organisation of South Africa, had withdrawn as late as at the end of 1975 their financial and moral support of the Olympiad for the Disabled. The reason for this change of attitude was a resolution of the United Nations passed against apartheid in November 1975, which, however, clearly stated in paras. 3/4 that those sports organisations struggling against apartheid should be commended.

In this respect it must be noted that our South African Member Organisation of Sport for the Disabled was the first to make a breakthrough in apartheid in sport in that country, and their constitution was in absolute accordance with the constitutions of both the International Stoke Mandeville Games Federation (I.S.M.G.F.) and the International Sports Organisation for Multi-Disabled (I.S.O.D.). Moreover, during a visit to South Africa in March 1975 to attend a Congress, I had the opportunity of having a meeting with Dr Koornhof, Minister of Sport of the South African Government. He not only verbally in the presence of witnesses, but in an official letter to me, gave an absolute assurance that 'The South African Paraplegic team will be selected purely on merit regardless of colour, race or creed. The official policy of the South African Government is to give each sportsman and woman, regardless of race, creed or colour full opportunities to reach the top in sport, to participate against the best in the world also on an equal basis. All sportsmen and sportswomen from anywhere in the world are most welcome to participate in South Africa on an absolute equal basis in every respect as is the case anywhere in the world, regardless of race, colour or creed.' Yet this clear declaration, confirmed again later, was considered by the Canadian Federal Government as 'Tokenism or Window dressing', in spite of the fact that it was made quite clear that sport for the disabled is not an end in itself, but a means of their rehabilitation and, in particular, social reintegration into the community. It will be shown later how this attitude of the Government of the host country became the prelude to political pressure and blackmail by other countries. 

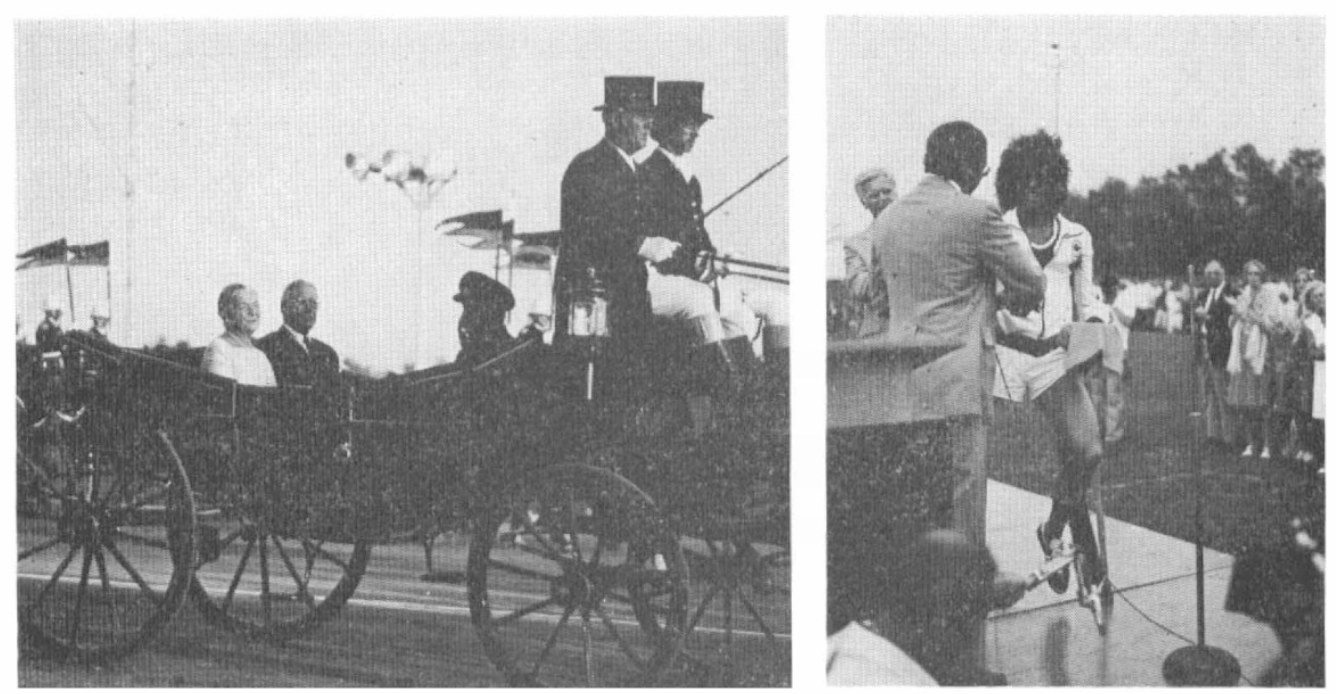

FIG. 3 (left)

Lt. Governor, the Hon. Pauline McGibbon arriving for the opening ceremony of the Games.

Fig. 4 (right)

Arnold Boldt (Canada) a high single leg amputee. The outstanding athlete of the Games.

The dilemma caused for our Canadian Organising Committee was that the Provincial Government of Ontario and Metropolitan Government of Toronto were coupled with the Federal Government in their pledge to give 500,000 dollars each, and unless they were uncoupled it would be impossible to hold the Olympiad in Toronto on the large scale as envisaged. Fortunately, as the result of discussions Dr Jackson and myself had with representatives of these authorities, the Ontario Government and the Metropolitan Government uncoupled themselves from the Federal Government and kept their promise to support the Games morally as well as financially. Moreover, press, radio and television gave their fullest support and objected to the attempt to use even the Games for the Disabled as a political pawn. Moreover, industry and commerce and many individuals made essential contributions financially and in kind to fill the gap. To give an example, Mr George Brown, a Canadian Industrialist, most generously provided track suits to all competitors of all countries taking part in the Games. The Executive Committees of I.S.M.G.F. and I.S.O.D. decided to raise the usual contribution of each competitor and escort from $£ 2$ to $£ 3$ and to encourage participating teams to make further contributions if possible.

\section{Accommodation}

\section{Planning and Organisation}

Although the accommodation in both Universities was excellent and the food superb, the fact that it was not possible to accommodate all competitors and escorts together and, moreover, far away from the Games site proved to be a disadvantage, but in the circumstances one had to accept this. Added to this difficulty was the lack of communication between the two universities, aggravated by the lack of a P.A. system. 

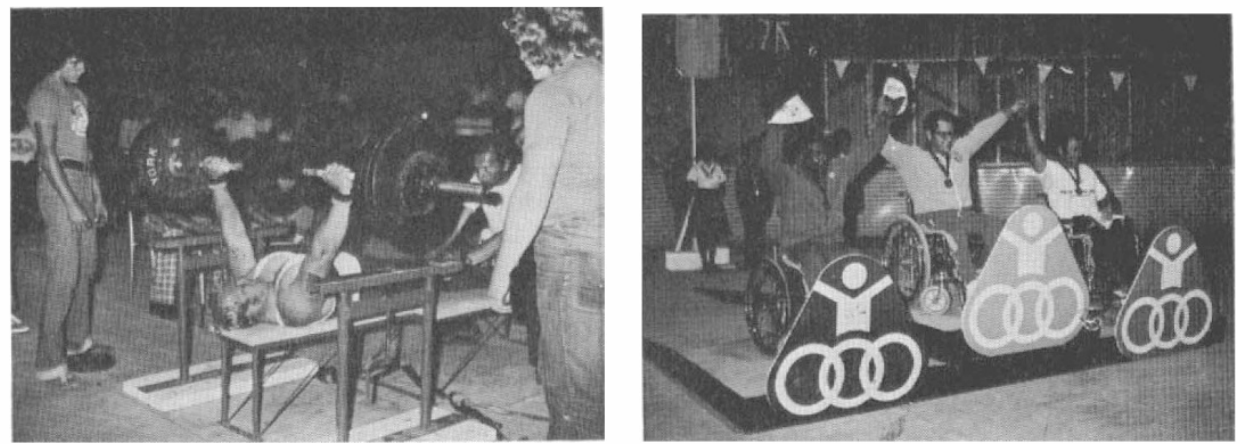

Fig. 5 (left)

Heavyweight weight lifting contest. Gold, Brown (U.S.A.): 240 kilos.

Fig. 6 (right)

Light heavyweight weight lifting contest. Gold, Strauch (Israel); Silver, Rowe (Great Britain); Bronze, Creba (New Zealand).
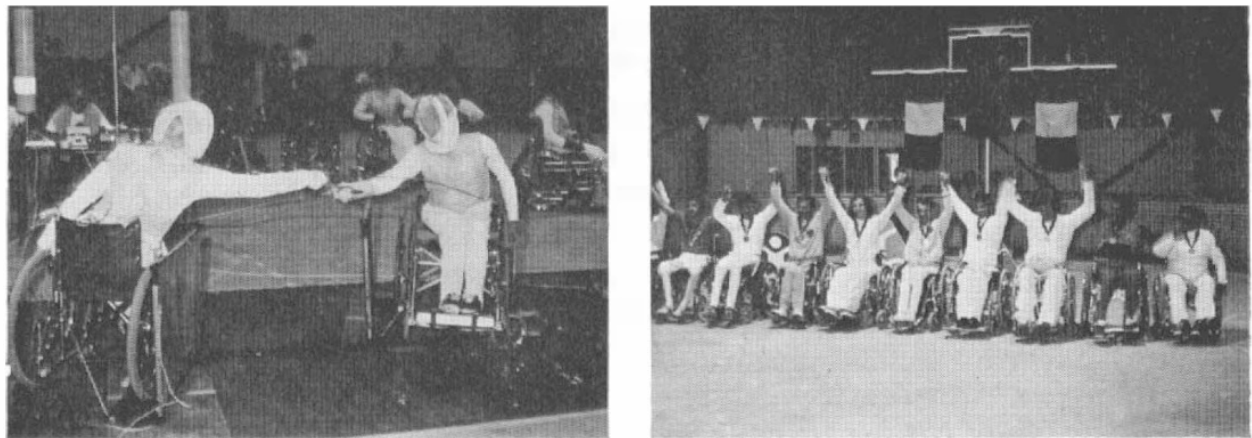

FIG. 7 (left)

Fencing contest in progress.

FIG. 8 (right)

Winners of fencing team foil (Class 3/4). Gold, Germany; Silver, France; Bronze, Italy.

\section{Transport}

This was set up between the universities and the Games site and was carried out by many specially adapted buses. Having regard to the long distances from the universities to the Games site, the transfer by buses worked as a whole satisfactorily, due a great deal to the full cooperation of the team leaders, escorts and the competitors themselves.

\section{Games Site}

This was the Centennial Park of the Borough of Etobicoke and the Olympium. The latter had been completed in good time and was really a magnificent building with easy access for severely disabled, particularly those in wheelchairs-really an example of how a modern sports stadium should be built to ensure free access of both able-bodied and disabled athletes.

$$
14 / 3-E
$$



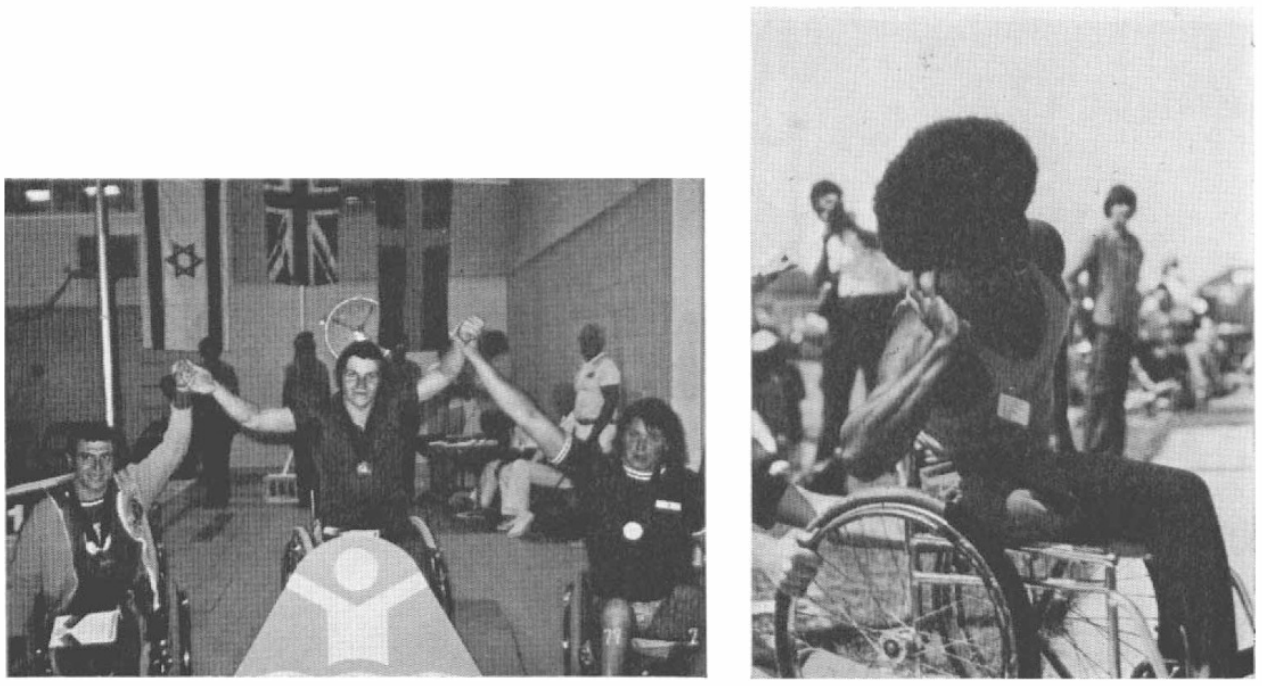

Fig. 9 (left)

50 metre Butterfly Class 5 (Paraplegic). Gold, D. Bonnar (G.B.) 37.96 sec; Silver, M. Cohen (Israel) 38.60 sec; Bronze, L. Anderson (Sweden) 4I·9I sec.

Fig. Io (right)

Bahamas competitor in shot put, paraplegic and one leg amputee.

\section{Organisation of Sports Events}

This was basically centred around a computer system. As in other applications of a computer system, the output can only be adequate if the input is correct, and in dealing with human problems such as a large sports event for physically disabled, human errors are inevitable. To quote only a few instances affecting the British team; one of our female table tennis competitors was wrongly entered by the computer for snooker (a men only event) and in swimming, to take place simultaneously, and in another instance it took our Assistant Team Manager some time to convince the organiser and the computer that one of our female competitors was not a male. There were also mistakes amongst teams from other countries. However, in all fairness, it must be stressed that alterations resulting from incorrect nomination of competitors, medical re-classification and, in particular, from the withdrawal of teams as the result of their governments' political interference added to the difficulties, resulting in an initial discontent amongst team managers, coaches and competitors. However, order was restored soon by adjustments and special arrangements which secured a smooth running of the Games. The sports events were controlled by qualified international referees of the I.S.M.G.F. in cooperation with national Canadian referees. Naturally, as in previous international sports competitions, sometimes discrepancies arose between international judges or referees with the officials of the host country. However, this did not interfere with the running of the competitions as a whole.

\section{Medical Classifications}

As in all previous Games, the competitors had to be classified according to their physical deficit to check their own national medical classifications, and in 
particular to classify competitors of those countries who took part for the first time. The classification of the competitors was based on the classifications of I.S.M.G.F. and I.S.O.D. elaborated by a medical panel set up by the Executive Committees of these two organisations. In Toronto, the medical panel of the I.S.M.G.F. worked under the leadership of Dr van der Maas from Holland and Dr McCann of the U.S.A. in close cooperation with the Canadian doctors and physiotherapists, who all did a magnificent work examining over I 400 participants. It is significant of their skill that relatively few protests regarding re-classification were made.

\section{Medical Supervision of the Games}

This was very satisfactory, as nearly every team brought its own medical officer and, moreover, the work of our Canadian colleagues in the field hospital was magnificent. There were extremely few more serious casualties. One blind member of the British team fell ill with a pleurisy for which, however, he received immediate, specialised in-patient hospital treament, and he recovered quickly. Another was the collapse of an Egyptian swimmer, who, however, soon fully recovered.

\section{Scientific Meeting of the International Medical Society of Paraplegia}

This Society, founded in I960, hold their Annual Scientific Meetings always in connection with the Stoke Mandeville Games, and this year their meeting took place at the newly built magnificent Lyndhurst Hospital for the Paralysed. The scientific programme included over 40 papers on physiological and clinical subjects as well as on pathology and pathogenesis, followed by interesting discussions. About 200 doctors and physicians, surgeons and paramedical personnel from many countries attended. The first part of the proceedings will appear in the February issue 1977 .

\section{Salute to the Games}

\section{Official Ceremonies}

The first official ceremony was held at Queen's Park, Toronto, the residence . of the Lt. Governor, the Hon. Pauline McGibbon. This was called 'Salute to the Games', where the flag of the Montreal Olympic Games was lowered and the flag of the Olympiad for the Physically Disabled hoisted; indeed, a rather emotional moment for all taking part. The Lt. Governor performed the official opening of the Salute, a Minister of the Ontario Government gave the opening address followed by addresses from Mayor Dennis Flynn of the Borough of Etobicoke, Dr Jackson as Chairman of the Organising Committee and myself as President of the Games.

\section{Opening Ceremony of the Games}

This was held at the magnificent Woodbine Race Track and was attended by no less than 24,000 spectators filling every seat at the Woodbine Race Track. Prior to the Parade of the Nations, which is a customary procedure of these International Games, several entertainments were given by rhythmic gymnasts; the Jim Sky Six-Nation Dancers, Indians on foot and on horses, and a musical ride by the 
Metropolitan Toronto Police, the band being that of the Royal Regiment of Canada. Dr and Mrs Jackson and myself welcomed the Lt. Governor Pauline McGibbon and her husband, who arrived in a carriage escorted by Metropolitan Police on horses. Other distinguished guests were Mr William G. Davis, the Prime Minister of the Ontario Government, Minister Welsh of the Ontario Government, Mr Godfrey, Chairman of the Metropolitan Government of Toronto, Mayor Flynn, and Ambassadors or their representatives of nations, the Chairman of the Canadian Paraplegic Association and members of the Executive Committees of I.S.M.G.F. and I.S.O.D. The Salute of the Parade of Nations was taken by the Lt. Governor, Dr Jackson and myself, and the Lt. Governor officially opened the Games. The Olympic torch was lighted and a Canadian competitor took the Games Oath. The teams of nations were greeted with a tremendous applause of welcome by the large crowd of spectators; it may be noted that the South African team received a specially enthusiastic welcome and there were no anti-demonstrations whatsoever.

\section{Intermediate and Closing Ceremonies}

Other ceremonies were the Ontario Night at York University, also attended by the Lt. Governor, and a Minister of the Ontario Government, furthermore, a Reception was given by Mayor Flynn and a 'thank you' Reception for the members of the Committee and helpers given by Dr Jackson and myself.

The closing ceremony was attended by a very large crowd in the presence of the Minister of Social Affairs of Ontario. It is the custom at the International Stoke Mandeville Games to present wheelchairs to teams of developing countries and this custom was also maintained this year. After the closing ceremony which was officially performed by Mayor Flynn, there was a 'get together' of all competitors, escorts and officials of all the nations taking part at York University, which was a most enjoyable occasion and contributed greatly in promoting friendship amongst the athletes and escorts of the many countries.

\section{Publicity of the Games}

The publicity and public relations for our Olympics were most satisfactory. The graphic symbol of the Games designed by Peter G. Robinson, was repeated on posters, advertisements, signs, letter headings, television programmes, souvenirs, etc., which in itself was good publicity. The Canadian press, radio and television media played a most active and very important part from the beginning and throughout the Games, and no praise is high enough for the support our Olympics received by these media. There was a daily detailed coverage on the lines given to that of the Olympic Games for the able-bodied in Montreal. A daily news sheet was produced which was very popular with all the teams, and Dr Jackson and I had daily press conferences in the afternoons, so that the public were well informed of the details of performances, including interviews of escorts and some outstanding sportsmen and women. In contrast to the excellent coverage of the Games by the Canadian press, etc., other countries varied considerably in the reportage of the Games and in some countries, including the television media of Great Britain in particular, the scanty reportage of the Olympiad for the Disabled was in utter contrast to the daily extensive reportage of the Montreal Olympics, which reveals an astounding lack of appreciation of the value of the sports movement of the disabled in educating the public. 


\section{Intrusion of Politics}

In all previous international sports festivals in England as well as abroad such as Italy, Japan, Israel and Germany, our Games have been completely free of political, racial and religious prejudices, in contrast to the Olympics of the ablebodied, bedevilled by politics and racial pressures, especially in Mexico and Munich, finally resulting in the massacre of the Israeli team during the Munich Olympics. Indeed, the International Games for the Paralysed and other Disabled succeeded in bringing together teams from countries taking part from all over the world, including those where tension, if not outright hostility, existed, such as between Egypt and Israel, and our Games were always held in accordance with the I.S.M.G.F.'s ideals of Friendship, Unity and Sportsmanship, symbolised in the three entwined wheelchair wheels. It was, therefore, most deplorable that certain countries used even the disabled sportsmen and women as a political pawn, which took the form of either not sending teams, although they originally applied for participation (Kenya, Sudan and Yugoslavia), or when the teams arrived, they were ordered by their Embassies to withdraw (Cuba, Hungary, India, Jamaica and Poland). This was the more deplorable as the teams of the countries just mentioned took part in the Olympiad of the able-bodied, in spite of the withdrawal of many other countries in protest against the participation of New Zealand, which allowed its rugby team to compete in South Africa with a non-racially integrated all white team. To deny their severely disabled sportsmen and sportswomen the right to participate in their sports festivals is not only a travesty of sportsmanship but is an act against the most fundamental principles of rehabilitation and human understanding. In this connection, it must be stressed that this action of those countries who prevented their teams of disabled sportsmen and women from participating in the Games was in utter contrast to the accepted United Nations General Assembly's 'Declaration on the Rights of Disabled Persons' of 9th December 1975 (347, XXX) which calls for national and international action to ensure that it will be used as a common basis and term of reference for the protection of these rights. To quote only a few paragraphs of this humane declaration, paragraph 2 of the Declaration may be quoted: 'Disabled persons shall enjoy all the rights set forth in this Declaration. These rights shall be granted to all disabled persons without any exception whatsoever and without distinction or discrimination on the basis of race, colour, sex, language, religion, political or other opinions, national or social origin, state of wealth, birth or any other situation applying either to the disabled person himself or herself or to his or her family' and paragraph 6 is even more specific: 'Disabled persons have the right to medical, psychological and functional treatment, including prosthetic and orthotic appliances, to medical and social rehabilitation, education, vocational training and rehabilitation, aid, counselling, placement services and other services which will enable them to develop their capabilities and skills to the maximum and will hasten the process of their social integration or reintegration.' A further paragraph to be quoted is paragraph Io: 'Disabled persons shall be protected against all exploitation, all regulations and all treatment of a discriminatory, abusive or degrading nature'.

It was pathetic to see the bitter resentment and frustration of leaders of teams who had to withdraw their teams when they came to inform us about the decision of their Governments, not to mention the despair of the competitors themselves, who were not only looking forward to the reunion with their disabled comrades but had trained so hard for a long time to represent their countries in their Olympiad.

The reaction of the competitors of the remaining 38 countries of every race and 

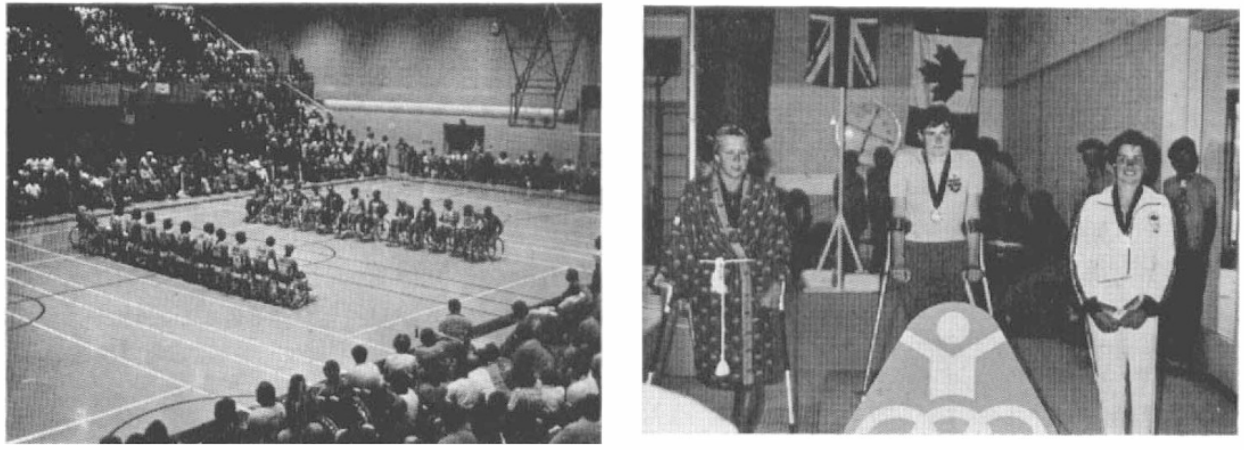

FIG. I I (left)

Finalists in Wheelchair Basketball, Israel and U.S.A. Gold, U.S.A.; Silver, Israel.

FIG. I2 (right)

Ladies Ioo metre backstroke swimming competition of high above knee amputees. Gold, Miss M. Vaughan (G.B.); Silver, Miss B. Samlelsson (Sweden); Bronze, Miss J. Mitchell (Canada).
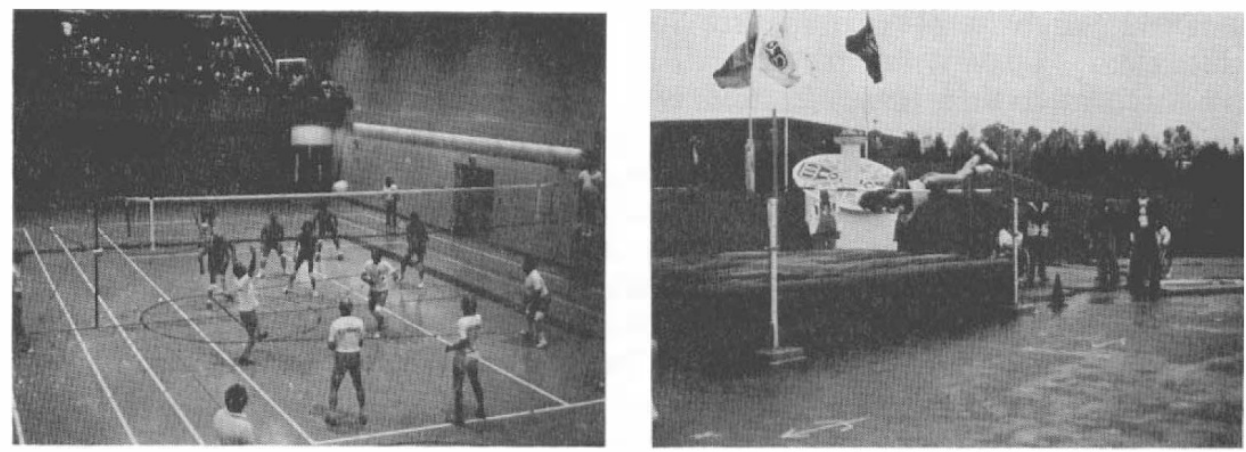

FIG. I3 (left)

Volley ball contest of amputees between Finland and Great Britain. In the final Israel won the Gold, Great Britain the Silver, and Finland the Bronze.

FIG. I4 (right)

Blind competitor in high jump competition.

colour including Bahamas, Ecuador, Egypt, Ethiopia, Fiji, Indonesia, Israel, Japan, Korea, Philippines, is best shown by the fact that one distinguished Australian sportsman declined to accept his gold medal, in protest of all competitors to those governments which tried to use sport for the disabled as political blackmail. In other circumstances such a competitor who refused a gold medal for political reasons would have been expelled from our Games. However, realising the deep resentment of the remaining over 1000 competitors, it was a duty for me, as President, to call a public meeting of competitors, escorts and the public, where the press, radio and television were invited, to express in public our protest at this political interference. The Australian sportsman was allowed to explain the reason for his action in declining acceptance of the gold medal. At the end of his speech, he presented the gold medal to me as President, which, in turn, I put around his 

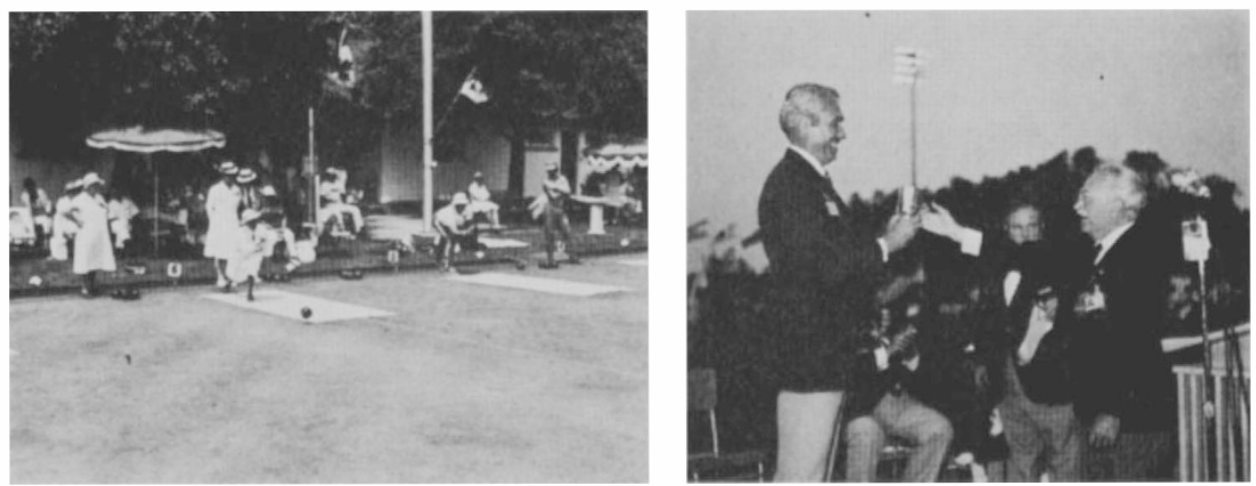

Fig. I5 (left)

Blind in bowling competition.

FIG. I6 (right)

Sir Ludwig Guttmann, President of I.S.M.G.F. and I.S.O.D. presents Dr R. W. Jackson, the Chairman of the Canadian Organising Committee, with an inscribed tankard at the closing ceremony.

neck and which he then accepted. This episode shows best the resistance and condemnation of the competitors and escorts of the participating countries to the attempt at introducing politics into the sports movement of the physically handicapped. It was most gratifying that the political interference of those countries mentioned above did not disrupt our Toronto Olympiad, and in particular the standard of performances of the competitors in the Games.

The reaction of the Praesidium of I.S.M.G.F. as well as I.S.O.D. towards the introduction of politics in our Games was to stand firm to our ideals, and a proposal made by one country to expel the South African team was unanimously rejected. On the other hand, the Praesidium, recognising that the departing teams were forced to do so by political pressure, decided not to expel the teams of those countries, but it was made quite clear that if in future they want to take part in these Games for the Disabled they will have to comply fully with our constitutions.

\section{Standard and Records of Performances}

The standard of performances in all sports events was high and as in the Olympics for the able-bodied, national, Olympic and world records were again broken in various events. This Olympiad gave the opportunity for competitors of countries taking part for the first time, such as Brazil, Burma, Fiji, Guatemala, Hungary and Peru, to enter world class competition and some showed good skill and even succeeded in winning medals. In spite of the various difficulties new friendships between competitors and escorts were formed and old ones renewed. This natural attitude of respect and friendship between sportsmen was exemplified by Egypt and Israel, when in one of the swimming competitions, Uri Berman, an Israeli amputee swimmer, won the gold medal in the Ioo metres free style race and Adolf Hafez of Egypt won the silver medal. The two men shook hands and then posed for photographers with their hands raised together in a victory salute, the two men who received their injuries in the war against each other, shook hands.

Table I shows the final medal placings of the teams of various nations and the 


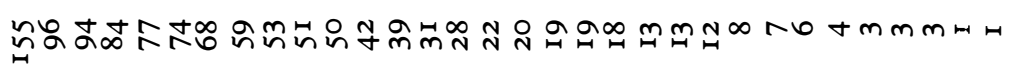

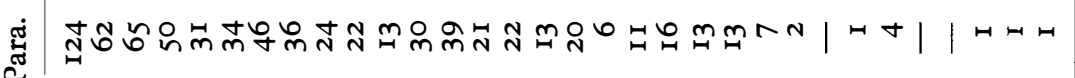

苟

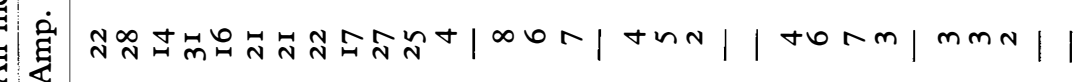

|

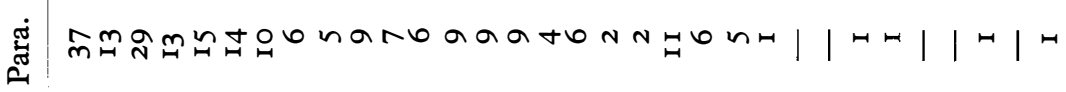

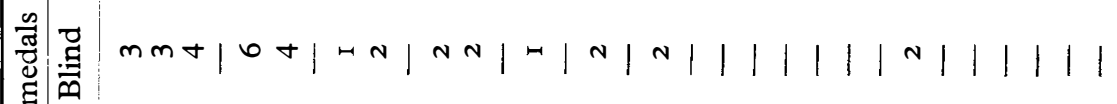

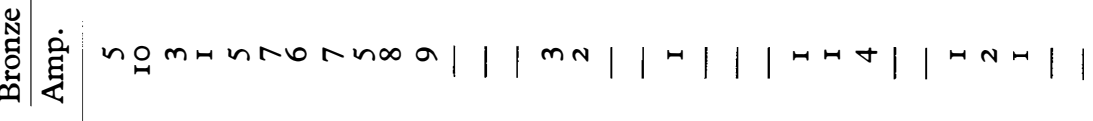

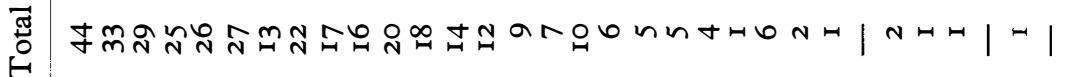

我

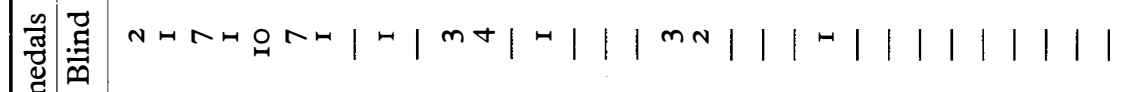

离究

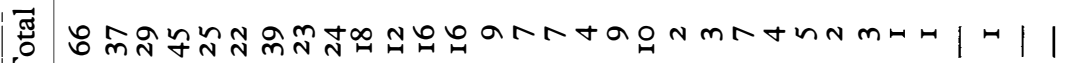

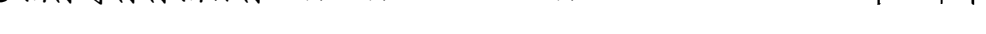

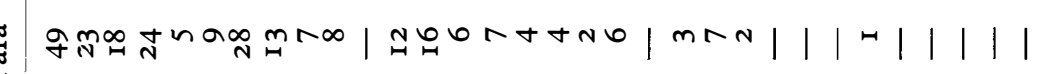

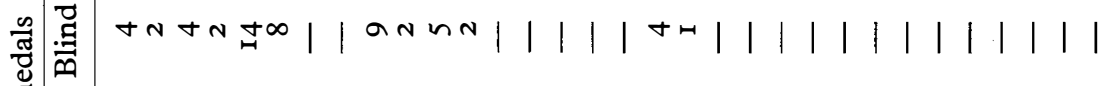

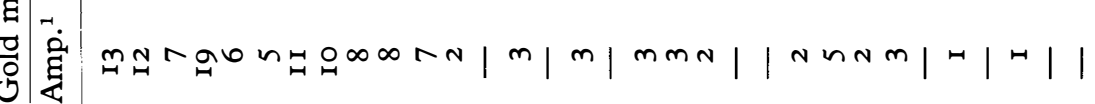

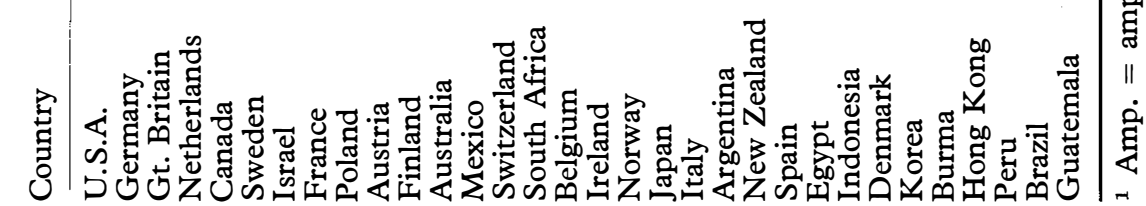


total numbers of medals awarded. Some outstanding achievements may be mentioned. Amongst the amputees Arnold Boldt, a Canadian single high leg amputee set a new world record of $\mathrm{I} \cdot 86$ metres in the high jump. He also won another world record with his long jump of 2.96 metres and was named at the closing ceremony as the outstanding athlete of the 1976 Olympiad. Miss Monica Vaughan from Great Britain, a high single leg amputee, won five gold medals, four of them in swimming-I00 metres butterfly I:23.2I, IO0 metres backstroke I:25.I9, IOO metres breast stroke $\mathrm{I}: 40.98$ and in the 200 metres individual medley her time was 3:03:67. Mr A. Beez from Germany, a single, below elbow amputee, threw 50:59 metres in javelin. Mr J. Nielson of Denmark, a double above elbow amputee, ran the 1500 metres in 5:28.60.

Amongst the blind, the 26-year-old British blind physiotherapist Jim Muirhead won a gold medal in the butterfly contest with a record of I:I 7.85 beating his opponent, Isaacs of Canada by I I seconds. In the 400 metres individual medley his time was $6: 29 \cdot 60$. In the javelin throwing contest T. Sulisalo, partially blind, from Finland threw 45.65 metres, D. Howie, Great Britain, partially blind, won the I 500 metres walk with a record of 6:34:40.

Amongst paraplegics, in the Novice round of Archery, Miss Yamasaki, Japan, scored 582 points (previously 46I). In the FITA round, a tetraplegic, Pimmelaar of the Netherlands scored 2126 points (previously 2095 points) and in the Tetraplegic round, Casperson, Netherlands, scored 610 points (previously 543 points). In the club throwing, Miss Corneto of Mexico threw I7.79 metres (previously 13.4I metres). In 25 metres backstroke swimming (Class IB) Miss Hilberink of the Netherlands swam it in $31.56 \mathrm{sec}$ (previously $43.40 \mathrm{sec}$ ). In the 50 metres breaststroke, Miss Bey, U.S.A. swam it in $49.86 \mathrm{sec}$ (previously $56.60 \mathrm{sec}$ ). Miss Susan Sherrill, tetraplegic, Great Britain (Class IA, no triceps, only extensors of the wrist, no finger movements) won a gold medal in the 25 metres backstroke in $36.35 \mathrm{sec}$ beating her previous world record $(38.50 \mathrm{sec})$. In the Ioo metres butterfly, $\mathrm{Mr}$ Bergman, Israel (Class 6) won a gold medal with I:I $4 \cdot 64$ (previous record I:26.40). In track events, the U.S.A. ladies team did I60 metres dash in $49.80 \mathrm{sec}$ (previously 58.IO sec). In weight lifting (Featherweight) Mr Nillson of Sweden pressed 175 kilos (previously 163.5) and in the lightweight, Coyle, U.S.A. pressed I77.5 kilos (previously I68.5 kilos). John Brown, the 32-year-old paralysed polio from California, U.S.A. won a gold medal in the heavyweight class and set up a new Olympic record by lifting 240 kilos. He was bitterly disappointed not to have succeeded in lifting 600 pounds. In Fencing, C. Thomas, G.B. won a gold medal in individual sabre and a silver in the individual épée, team épée and team sabre. T. Willett, G.B. won a gold medal in the individual épée, silver in team épée and in team sabre and a bronze in the individual sabre. In the fencing team events, the French team won the gold in épée and sabre and the British team won the silver. In the Team foil competition Germany won the gold, France the silver and Italy the bronze.

In the team sports, wheelchair basketball again proved, as always, to be the most exciting game, and in the finals a sell-out crowd packed the Olympium to watch the match between the finalist teams, Israel and the U.S.A. In the first half, Israel were in front by 25 to 22 , but in an exciting final half, the U.S.A. succeeded in retaining the Olympiad Championship they had won from Israel at the Olympiad in Heidelberg, then by only one point. This year, the final score was: U.S.A. 59, Israel 46. The outstanding players in the U.S.A. team were Ed Owen and David Keilye, while in the Israeli team, it was Hagai, who on the same afternoon, won the gold medal in the final table tennis match, defeating in two straight games 
Dempsey of the U.S.A. In Volleyball for amputees Israel won a gold, Great Britain a silver and Finland a bronze.

\section{ConcLusion}

I. It can be said that the I976 Olympiad for the Disabled in Toronto has been a great success, despite difficulties, and the Toronto Games will go into the history of sport of the disabled as a further milestone in the development of international sport for the physically handicapped.

2. The standard of performance in various sports events at the Toronto Games was greatly increased as compared with previous international Games and national, Olympiad and World records were broken. The spirit of sportsmanship amongst the competing teams was excellent which helped very much in overcoming difficulties.

3. The Canadian press, radio and television media gave superb publicity and full reportage of the sports events-indeed a shining example to those media of other countries who still show distinct lack of understanding and cooperation in this respect.

4. Above all, the Toronto Games, like the preceding international games of the disabled, were an eye-opener and a great education to the public about the significance of sport for the disabled. They aroused great enthusiasm and emotion amongst the more than 100,000 spectators attending the Games and the public at large.

5. The difficulties experienced during the Games with accommodation and transport highlighted the great need for the host country to provide similar facilities to those always provided at enormous costs for international sports events of the able-bodied, including the Olympic Games. This would be in absolute accord with the United Nations 'Declaration of the Rights of the Disabled' of 15 November I975 and indeed its full implementation.

6. For the first time in the history of international sport of the physically disabled, we were the victims of political and racial pressure. It is most deplorable that certain countries, in defiance of the resolutions of the United Nations, tried to use the Games of the Amputees, Blind and Paralysed as a political pawn, thus denying their disabled citizens the right to take part in this event of sport, rehabilitation and humanity. The international committees of I.S.M.G.F. and I.S.O.D., as well as the disabled athletes and their escorts themselves were unanimous in their resistance and condemnation of this attempt of introducing politics into the sports movement of the disabled. If any lesson were to be learned for all countries from these sad events in both the Toronto and the Montreal Games, it is surely that national, racial and religious prejudices and politics must be firmly and radically banned from sport.

\section{RÉSUMÉ}

On peut dire qu'en dépit des diverses difficultés rencontrées, l'Olympiade des Handicapés à Toronto en 1976 a remporté un vif succès, et que les Jeux de Toronto entreront dans l'histoire du sport pour handicapés comme un nouveau jalon posé sur la voie du sport international pour les handicapés physiques.

Le niveau des performances dans les différents sports aux Jeux de Toronto s'est grandement amélioré par rapport aux Jeux internationaux précédents et des records nationaux, olympiques et mondiaux ont été battus. L'excellent esprit sportif qu'ont manifesté les équipes de concurrents a contribué pour une large part à surmonter les difficultés.

La presse, la radio et la télévision canadiennes ont largement publié et complètement suivi les manifestations sportives, donnant ainsi un magnifique exemple aux media des 
autres pays qui accusent encore à cet égard un net manque de compréhension et de coopération.

Les Jeux de Toronto, comme les autres Jeux internationaux pour handicapés, ont surtout permis d'ouvrir les yeux du public et de lui faire mieux comprendre l'importance du sport pour les handicapés. Ils ont suscité beaucoup d'enthousiasme et d'émotion chez plus de 80.000 spectateurs qui assistaient aux Jeux et dans le grand public.

Les problèmes de logement et de transport qui se sont posés pendant les Jeux mettent en lumière la nécessité pour le pays hôte de fournir des facilités semblables à celle qui sont toujours mises sur pied à grand frais pour les manifestations sportives internationales des valides, y compris les Jeux Olympiques. Ceci serait en harmonie absolue avec la 'Déclaration des Droits de l'Handicapé' des Nations Unies du I5 novembre 1975, et constituerait sa mise en application totale.

Pour la première fois dans l'histoire du sport international pour les handicapés physiques, nous avons été victimes de pressions politiques et raciales. Il est vraiment déplorable que certains pays, faisant fi des résolutions des Nations Unies, essaient de se servir des Jeux pour Amputés, Aveugles et Paralysés comme d'un gage politique, refusant ainsi à leurs handicapés le droit de prendre part à cette compétition de sport, de réhabilitation et d'humanité. Les comités internationaux de l'I.S.M.G.F. et de l'I.S.O.D., de même que les athlètes eux-mêmes ainsi que leurs escortes, ont été unanimes à résister et à condamner cet essai d'introduire la politique dans le mouvement sportif pour handicapés. Si une leçon doit être tirée par tous les pays de ces événements des Jeux du Toronto et de Montréal, c'est bien que les préjugés nationaux, raciaux et religieux, de même que la politique doivent être fermement et radicalement bannis du sport.

\section{ZUSAMMENFASSUNG}

I. Die I976 Toronto Olympiade war eine grosser Erfolg trotz verschiedener Schwierigkeiten. Sie werden in die Geschichte des Sportes als ein weiterer Meilenstein für die Entwicklung des Sportes für Körperbehinderte eingehen.

2. Der Standard der Leistungen in den verschiedenen Sportarten war im Vergleich mit früheren Olympiaden erheblich verbessert und Nationale, Internationale, Olympische und Weltrekorde wurden gebrochen. Der Sportgeist der Wettkämpfer war ausgezeichnet, was erheblich geholfen hat, Schwierigkeiten zu überwinden.

3. Die Kanadische Presse, Radio und Television gab unserer Olympiade ausgezeichnete Publizität und ausführlichst Reportage, in der Tat ein leuchtende Beispiel für die Media anderer Länder, die immer noch einen deutlichen Mangel an Verständnis und Ko-operation in diese Beziehung zeigen.

4. Vor allem die Toronto Olympiade erzieherisch und lehrreich auf die Allgemeinheit für ein besseres Verständnis des Sportes für Körperbehinderte. In der Tat diese Olympiade löste grosse Begeisterung bei den mehr als I00,000 Zuschauern aus.

5. Die Während der Spiele entstandenen Schwierigkeiten mit den Unterkunfts möglichkeiten und Transport bestätigen nachdrücklichst die absolute Notwendigkeit für jedes Land, das diese internationalen Spiele für Körperbehinderte im Olympischen Jahr organisiert, dieselben Unterkunfts, Transport-und Wettkampfmöglichkeiten zu schaften wie dies seither mit enormen Kosten für internationale Sportwettkämpfe inclusive die Olympischen Spiele für Nicht-Körperbehinderte die Regel ist. Solch eine Einstellung würde der jüngsten Deklaration der Vereinigten Nationen (I5. November 1975) "Uber das Recht der Körperbehinderten" absolut entsprechen und in die Tat umsetzen.

6. Zum ersten $\mathrm{Mal}$ in der Geschichte des internationalen Sports für Körperbehinderte wurden wir Opfer politischer und rassischer Ideologien. Es ist ausserordentlich bedauerlich, dass einige Länder in absoluter Missachtung der Resolutionen der Vereinigten Nationen versuchten, die Spiele der Amputierten, Blinden und Spinalgelähmten als politischen Spielball zu benutzen. Mit dieser Aktion verhinderten sie ihre eigenen körperbehinderten Volksgenossen an dieser Olympischen Feier des Sportes, der Rehabilitation und Humanität teilzunehmen. Die internationalen Kommitees der ISMGF und ISOD und vor allem auch die körperbehinderten Wettkämpfer und ihre Eskorten waren einstimmig in ihrer Resistenz und Verurteilung des Versuchs, Politik in die Sportbewegung der Körperbehinderten einzuführen.

Wenn eine Lehre aus diesen bedauerlichen Vorgängen der Olympischen Montreal und Toronto Spielen für alle Länder gezogen werden kann, so muss es der feste Wille sein, politiche, rassische und religiose Vorurteile aus dem Sport für immer und radikal auszuschalten. 


\section{Postscript}

A resolution was passed in the Canadian Parliament to support the decision of the Medallic Marketing Trust of Canada to mint a commemorative coin in gold, silver and bronze to help defray the deficit of the Games. This was accepted unanimously as shown in the official transcript of the Canadian Hansard of I9th October 1976 which follows.

\section{ROUTINE PROCEEDINGS: OLYMPIAD FOR THE DISABLED}

Suggested Support for Fund Raising Activities: Motion Under S.O. 43

Mr Otto Jelinek (High Park-Humber Valley): Mr Speaker, pursuant to Standing Order 43 I rise on a matter of urgent and pressing necessity. In view of a substantial deficit incurred by the organising committee for the 1976 Olympiad for the physically disabled held earlier this year in Toronto, the Olympiad is embarking on a worldwide sale of precious metal commemorative medallions to honour Sir Ludwig Guttmann, the originator of organised sport for the disabled. In that funds generated will be used to offset the current deficit and to further the cause of organised sports for the disabled worldwide, I move, seconded by the hon. member for Hamilton Mountain (Mr MacFarlane): That this House support and encourage the Olympiad for the disabled in their current fund raising program.

Some hon. Members: Hear, hear!

Mr Speaker: Order, please. Such a motion can be presented only with the unanimous consent of the House. Is there unanimous consent ?

Some hon. Members: Agreed.

Motion agreed to. 